\title{
A Cytological Study of Peritoneal Fluids and Its Clinicobiochemical Correlation.
}

\author{
DR. Shikha $\mathrm{NG}^{1}$ \\ ${ }^{I}(M D$, Senior Resident, Pathology Dept., RIMS, Imphal, India)
}

\begin{abstract}
The study was a comparative evaluation of the physical and Bio-chemical components of ascitic fluid in different disease conditions associated with ascites e.g. Malignancy, Tuberculosis, Liver Cirrhosis, C.C.F., Nephrotic Syndrome, Anaemia-Hypoproteinemia \& Spontaneous bacterial peritonitis. The study also highlights disease wise age and sex incidence.
\end{abstract}

Keywords: Ascites, cytology, peritoneal fluid, cirrhosis

\section{Introduction}

Ascites means presence of excess fluid in the peritoneal cavity, normally upto $50 \mathrm{ml}$ of fluid is present. Ascites is a common clinical condition that poses a diagnostic problem to the clinicians. Some of the causes of peritoneal effusions include congestive cardiac failure, cirrhosis, neoplasms and infections. Transudates are clear fluids with a low protein content and a glucose content similar to serum .Exudates are slightly hazy fluids with a high protein content and low glucose.

Jain SR et al ${ }^{[1]}$ found that in cases of tuberculosis, the ascitic fluid sugar was low compared to blood sugar. Gorozhansky et al ${ }^{[2]}$ stated that ascites from malignant neoplasms had high glucose content.The correct diagnosis of the fluid as transudate or exudate is important because if the fluid is exudative then further diagnostic procedures like cytopathology, biopsy and other invasive procedure can be done. On the other hand, if transudative then treatment can be given.

The differentiation of the fluid into malignant or non-malignant fluid has a deep impact on the course of the treatment to be followed. The presence of cancer cells in the fluid is a proof positive of malignancy related fluid but in 30 to 60 percent of cancer cases, cancer cells are not detected. Exfoliative cytology for malignant cells is highly specific though less sensitive $(40-60 \%)^{[3]}$.

The present study is undertaken to detect malignancy, differentiate ascitic fluids into transudates and exudates by using fluid protein parameter and also to correlate with clinical findings.

\section{Materials And Methods}

A prospective study was carried out at a teaching hospital in Navi Mumbai over a period of two and a half years from May 2009 till October 2011. A total number of 50 cases (ascitic fluids) were studied.

Fluid for routine analysis and cytology was done in respect of physical examination and microscopic examination by noting the appearance and colours. Total WBC count and RBC count of fluid was carried out using Neubauer's chamber. The sediment, smears were prepared and stained by field's and leishman stain for differential count and papanicolaou stain for cytology. The supernatant fluid was analysed for biochemical parameters (fluid protein and sugar).

\section{Criteria for selection of patients:}

The patients presenting with ascites were taken into account. All cases were clinically diagnosed. Patients of nephrotic syndrome, severe anemia-hypoproteinemia, spontaneous bacterial peritonitis were also included in this study.

III. Results

TABLE NO.1: ETIOLOGICAL CLASSIFICATION OF 50 CASES OF ASCITIC FLUIDS

\begin{tabular}{|l|c|c|}
\hline \multicolumn{1}{|c|}{ Diagnosis } & No. of cases & $\%$ \\
\hline Liver cirrhosis & 29 & 58 \\
\hline Nephrotic syndrome & 7 & 14 \\
\hline & 5 & 10 \\
\hline
\end{tabular}


A Cytological Study Of Peritoneal Fluids And Its Clinicobiochemical Correlation.

\begin{tabular}{|l|c|c|}
\hline Anaemia-hypoproteinemia & & \\
\hline Tuberculosis & 4 & 8 \\
\hline Malignancy & 2 & 4 \\
\hline $\begin{array}{l}\text { Congestive cardiac failure } \\
\text { ppontaneous bacterial }\end{array}$ & 2 & 4 \\
\hline Total & 1 & 2 \\
\hline
\end{tabular}

Liver cirrhosis (58\%) was found to be the most common cause of ascitic fluids.

Table No.2 :Age and sex distribution of 50 ascitic fluid cases.

\begin{tabular}{|l|c|c|c|c|c|c|c|c|}
\hline \multirow{2}{*}{ Diagnosis } & \multicolumn{2}{c|}{ Gender } & \multicolumn{7}{c|}{ Age (years) } & Total \\
\cline { 2 - 9 } & Female & Male & $\begin{array}{c}10- \\
20\end{array}$ & $\begin{array}{c}20- \\
30\end{array}$ & $\begin{array}{c}30- \\
40\end{array}$ & $\begin{array}{c}40- \\
50\end{array}$ & $>50$ & \\
\hline Malignancy & $2(100 \%)$ & 0 & 0 & 0 & 0 & 0 & 2 & 2 \\
\hline Tuberculosis & $3(75 \%)$ & $1(25 \%)$ & 0 & 1 & 3 & 0 & 0 & 4 \\
\hline Cirrhosis & 0 & $29(100 \%)$ & 1 & 2 & 6 & 14 & 6 & 29 \\
\hline Nephrotic Syndrome & $3(42.9 \%)$ & $4(57.1 \%)$ & 0 & 1 & 2 & 3 & 1 & 7 \\
\hline $\begin{array}{l}\text { Anaemia- } \\
\text { hypoproteinemia }\end{array}$ & $3(60 \%)$ & $2(40 \%)$ & 2 & 0 & 0 & 1 & 2 & 5 \\
\hline CCF & 0 & $2(100 \%)$ & 0 & 1 & 0 & 0 & 1 & 2 \\
\hline $\begin{array}{l}\text { Spontaneous bacterial } \\
\text { peritonitis }\end{array}$ & $1(100 \%)$ & 0 & 0 & 0 & 1 & 0 & 0 & 1 \\
\hline Total & $12(24 \%)$ & $38(76 \%)$ & 3 & 5 & 11 & 18 & 12 & 50 \\
\hline
\end{tabular}

Male predominance was found in all the diseases (76\%) causing ascitis. Majority cases of liver cirrhosis (28\%) were found in $5^{\text {th }}$ decade.

Table no. 3: Gross appearance of fluid in 50 ascitis fluid

\begin{tabular}{|l|c|c|c|c|}
\hline \multirow{2}{*}{ Diagnosis } & \multicolumn{3}{c|}{ Colour } & \multirow{2}{*}{ Total } \\
\cline { 2 - 4 } & Straw & Turbid & Yellow & 2 \\
\hline Malignancy & 0 & 2 & 0 & 0 \\
\hline Tuberculosis & 4 & 0 & 20 & 29 \\
\hline Liver cirrhosis & 9 & 0 & 4 & 5 \\
\hline $\begin{array}{l}\text { Anaemia- } \\
\text { Hypoproteinemia }\end{array}$ & 1 & 0 & 6 & 7 \\
\hline Nephrotic syndrome & 1 & 0 & 1 & 2 \\
\hline CCF & 1 & 0 & 0 & 1 \\
\hline Spontaneous bacterial peritonitis & 0 & 1 & 31 & 50 \\
\hline Total & 16 & 3 & & \\
\hline
\end{tabular}

Table No. 4 : Distribution of Leucocyte count in 50 cases of ascitic fluid

\begin{tabular}{|l|c|c|c|c|}
\hline \multirow{2}{*}{ Diagnosis } & \multicolumn{3}{c|}{ Total WBC counts } & Total \\
\cline { 2 - 5 } & $<100 / \mathrm{cm} \mathrm{m}$ & $100-500 / \mathrm{cm} \mathrm{m}$ & $>500 / \mathrm{cm} \mathrm{m}$ & 2 \\
\hline Malignancy & 0 & 1 & 3 & 4 \\
\hline Tuberculosis & 0 & 1 & 0 & 29 \\
\hline Liver Cirrhosis & 25 & 4 & 0 & 7 \\
\hline Nephrotic Syndrome & 7 & 0 & 0 & 5 \\
\hline Anaemia-hypoproteinemia & 5 & 0 & 0 & 2 \\
\hline CCF & 2 & 0 & 0 & 1 \\
\hline Spontaneous bacterial peritonitis & 0 & 1 & 4 & 50 \\
\hline Total & 39 & 7 & & \multirow{2}{*}{5} \\
\hline
\end{tabular}


In case of liver cirrhosis, $(86.2 \%)$ showed W.B.C $<100$ cells /cmm with lymphocytic predominance .The solitary case of S.B.P showed W.B.C count $<500$ cells $/ \mathrm{cmm}$ with polymorph predominance

Table No. 5: Cytology of malignant fluids

\begin{tabular}{|c|c|c|c|}
\hline Fluids & No. of cases & Histopathological & $\begin{array}{c}\text { Malignant cells on } \\
\text { cytology }\end{array}$ \\
\hline Ascitic fluids & 1 & 1. Well differentiated Adenocarcinoma of lung & detected \\
\hline & 2 & $\begin{array}{c}\text { 2. Well differentiated adenocarcinoma of } \\
\text { lung }\end{array}$ & detected \\
\hline
\end{tabular}

Table No. 6: Categorization of Fluids Based on Diagnosis

\begin{tabular}{|l|c|c|c|}
\hline \multirow{2}{*}{ Diagnosis } & \multicolumn{2}{c|}{ Ascitis } & Total \\
\cline { 2 - 4 } & Exudates & 0 & 2 \\
\hline Malignancy & 2 & 2 & 4 \\
\hline Tuberculosis & 2 & 26 & 29 \\
\hline Liver Cirrhosis & 3 & 2 & 7 \\
\hline CCF & 0 & 6 & 5 \\
\hline Nephrotic syndrome & 1 & 5 & 1 \\
\hline Anaemia - Hypoproteinemia & 0 & 0 & 5 \\
\hline Spontaneous bacterial peritonitis & 1 & 41 & 50 \\
\hline Total & 9 & & 5 \\
\hline
\end{tabular}

\section{Discussion}

ETIOLOGICAL INCIDENCE: In the present study,cirrhosis was the most common cause of ascites ,comprising $58 \%$ of the cases. Spontaneous bacterial peritonitis was observed in one patient with incidence rate of $2 \%$ and the incidence of ascites in tuberculosis was found to be $8 \%$ which is slightly lower than the previous study ${ }^{[4]}$. The most probable reason for the decline in tuberculosis is early detection and early treatment of patients.

The incidence of nephrotic syndrome (14\%), anaemia hypoproteinemia (10\%) (table 1) and $\mathrm{CCF}(4 \%)$ are slightly higher than the previous workers ${ }^{[4,5]}$.

In the study the incidence of ascites due to malignancy was $4 \%$ which is slightly lower than the study by KhanT.H et al ${ }^{[6]}$.

\section{AGEWISE INCIDENCE OF ASCITES}

Most of the cases were in $5^{\text {th }}$ decade with majority of abdominal tuberculosis observed in $3^{\text {rd }}$ and $4^{\text {th }}$ decade and nephrotic syndrome in $5^{\text {th }}$ decade. In the present study, two cases of CCF were found, one in $3^{\text {rd }}$ decade and one in $4^{\text {th }}$ decade.

Both the cases of malignant ascites were found in older age group i.e. beyond $5^{\text {th }}$ decade, which in accordance with study by Mehrotra et $\mathrm{al}^{[7]}$.Anaemia-hypoproteinemia were found in 2 nd decade and in 5 th decade.

\section{SEXWISE INCIDENCE OF ASCITES}

In this study, $76 \%$ were patients and $24 \%$ were female.All cases of cirrhosis of liver were male whereas female predominance was seen in abdominal tuberculosis (75\%), anaemia -hypoproteinemia and malignancy $(100 \%)$. Male predominance was observed in case of CCF.

\section{ASCITIC FLUID GROSS EXAMINATION}

In cirrhosis, the samples of ascitic fluid were clear yellow or straw coloured and turbid ascitic fluid in spontaneous bacterial peritonitis, which is in accordance with reports from previous workers ${ }^{[4,6,8]}$.

Clear yellow or straw coloured ascitic fluid was found in nephrotic syndrome, CCF and tuberculous peritonitis.

In malignant ascitis, the flusid was turbid in all the cases, though most studies have reported hemorrhagic ascitic fluid ${ }^{[4,5,6]}$

\section{ASCITIC FLUID CYTOLOGY}

In this study the total WBC count of $<100$ cells $/ \mathrm{cmm}$ were seen in $86.20 \%$ of the cases of cirrhosis as compared to Jain S.C >et al ( $36 \%$ )[4,5] and between 100-500 cells/cmm were seen in $13.80 \%$. 
In case of spontaneous bacterial peritonitis, polymorph was predominant. In liver cirrhosis lymphocytic predominance was found in $93.1 \%$ of the cases as compared to Nath et al where it was 59\% [5].

In cases of nephrotic syndrome, CCF and anaemia-hypoproteinemia total WBC count of $<100 / \mathrm{cmm}$ with lymphocytic predominance was observed.

In tuberculous peritonitis, lymphocytic predominance was seen in all cases.

In the study the cases of malignant ascites showed $>100$ cells/cmm with lymphocytic predominance and exfloliative cytology for malignant cells was positive. Well differentiated adenocarcinoma of lung was diagnosed in both the cases.

\section{BIOCHEMICAL PARAMETERS}

In this study, a total of 50 fluids were studied, out of 50 ascitic fluids, 43 were found to be transudates and 7 were exudates. Transudates comprised cases of liver cirrhosis, nephrotic syndrome, anemiahyporoteinemia and CCF.

Exudates comprised cases of tuberculosis, malignancy and subacute bacterial peritonitis.

\section{Conclusion}

The study is conducted to evaluate the importance of the examination of Intra Peritoneal fluid in various disease conditions associated with intra peritoneal free fluid for clinicobiochemical correlation with the diagnosis of the underlying disease.

\section{References}

[1] Jain SR, Bhandari CR, Sugar in ascitic fluid: its value in the diagnosis of tuberculosis peritonitis, J Ass Physns India, 12, 1964, 71521.

[2] Gorozhanskaya EG, Gurevich BS, Content and some components of carbohydrate metabolism of ascites and pleural fluids in cancer patients, Fed proc, 24, 1965, 721-4.

[3] Runyon BA, Case of patients with ascites, N Engl J Med, 330, 1994, 337-342.

[4] Jain SC, Misra SM, Misra NP, Tandon PL, Diagnostic value of ascitic fluid examination, JAPI, 1965, 59-69.

[5] Nath K, Mital HS, Mishra SD, Mohan A, Diagnostics value of ascitic fluid examination, JAPI, 1968, 991-996

[6] Khan TH, Durrani HA, Ahmad Shah SN, Evaluation of peritoneal biopsy and ascitic fluid examination in the etiological diagnosis of ascitis, JAPI, 24, 1976, 579-585.

[7] Mehrotra MP, Saxena KK, Mathur DC, Etiological diagnosis of ascitis, Indian J. Med. Res, 60, 1972, 1089-1099.

[8] Tsao GG, Spontaneous bacterial peritonitis, Gastroenterology clinics of North America, 21, 1992,257-275. 